\title{
IDENTIFICATION AND CRITIQUE OF THE CITIZENSHIP NOTION \\ INFORMING THE ITORERO TRAINING SCHEME FOR HIGH \\ SCHOOL LEAVERS IN POST-GENOCIDE RWANDA
}

\author{
S. Nzahabwanayo \\ College of Education (UR-CE) \\ University of Rwanda \\ Kigali, Rwanda \\ e-mail: nzahabwanayo@yahoo.fr
}

\section{K. Horsthemke}

Katholische Universität Eichstätt-Ingolstadt, Germany

Wits School of Education, University of the Witwatersrand

Johannesburg, South Africa

e-mail: Kai.Horsthemke@ku.de; Kai.Horsthemke@wits.ac.za

\section{T. P. Mathebula}

Wits School of Education

University of the Witwatersrand

Johannesburg, South Africa

e-mail: Thokozani.Mathebula@wits.ac.za

\section{ABSTRACT}

There is a dearth of research on citizenship education in post-genocide countries. The present article investigates the citizenship concept informing Itorero, a non-formal citizenship education platform meant for High School Leavers (hereafter HSLs) in post-genocide Rwanda. To this end, the article engages with classical notions of citizenship such as civic republicanism, liberalism and communitarianism as well as modern ones, namely, cosmopolitanism and radical democracy, in a bid to identify the notion deemed preferable to these competing notions. It is revealed that the Itorero training relies heavily on the civic republican/communitarian concepts of citizenship. The article argues that while these concepts contain constructive elements, such as fostering courage, self-sacrifice, patriotism, connectedness, and common good concern, excessive pursuit of this citizenship model might not be helpful for post-genocide Rwanda. The civic republican/ communitarian paradigm as it is practiced in Itorero training is likely to produce uncritical and docile citizens. Perhaps paradoxically, it might also be seen to encourage fanaticism.

Keywords: citizenship, citizenship education, post-genocide Rwanda, Itorero, high school leavers, civic republicanism, communitarianism. 


\section{INTRODUCTION}

It is very possible that one of the root causes of the 1994 genocide perpetrated against the Tutsi in Rwanda is a distorted understanding of citizenship. The latter was confined to ethnic belonging. Since the Tutsi were portrayed by colonialists (both Germans and Belgians) as being of Hamitic origin, they were perceived in the eyes of fellow Rwandans as foreigners, as invaders and not really bona fide Rwandan citizens (Adejumobi 2001, 164-167; Kabwete Mulinda 2002, 50-51; Prunier 1995, 10-11). This situation suggests that one cannot envisage reconstruction, social cohesion and peace building in Rwanda while ignoring the issue of citizenship. As Davies (2005) points out, citizenship education is a crucial facet of reconstruction in post-conflict countries.

In this context, in addition to formal citizenship education, the Government of Rwanda (GoR) decided during the $12^{\text {th }}$ of November 2007 cabinet meeting to revive its traditional citizenship education program - which is 'Itorero' - to enable Rwandans to re-acquaint themselves with the values and taboos of their culture. This program was officially launched on the $16^{\text {th }}$ of November 2007, and in 2013 it became presided over by the National Itorero Commission (NIC), as per Law $\mathrm{N}^{\circ} 41 / 2013$ determining its mission, organization and functioning (GoR 2013). Pursuant to article 6 of the same law, its objective consists of: 'Bringing up a patriotic Rwandan who has values and taboos of the Rwandan culture and who has the culture of Intore'. Although this non-formal training is meant for all categories of Rwandans, it is compulsory mainly for all HSLs. The scheme designed for this category comprises two phases: (i) a theoretical phase called Gutozwa involving moral, political and cultural education for three months; and (ii) a practical phase named Urugerero in the form of national service or volunteerism for a period of seven months (National Itorero Commission 2012). This article focuses mainly on the theoretical phase and seeks to answer the following questions: What is the citizenship notion informing the Itorero training? Is the citizenship concept in question defensible and, in particular, appropriate for post-genocide Rwanda?

These questions are answered by engaging with classical notions of citizenship, namely, civic republicanism, liberalism, and communitarianism as well as modern ones such as cosmopolitanism and radical democracy. The article reveals that the Itorero training relies heavily on the civic republican/communitarian notions of citizenship. We argue that excessive pursuit of this model might not be appropriate for post-genocide Rwanda. The main argument is that the civic republican/communitarian paradigm as it is practiced in post-genocide Rwanda is likely to produce uncritical and docile citizens. Perhaps paradoxically, it might also be seen to encourage fanaticism. 
In the main, the present article contributes to the existing literature on citizenship education in two important ways. Firstly, although citizenship education has become a buzz word since the late $20^{\text {th }}$ century (Kymlicka and Norman 1994; Heater 1990; Vogel and Moran 1991), there is a dearth of research on the topic with regard to post-genocide countries. As a matter of fact, large scale citizenship studies, such as the 1971 International Association for the Evaluation of Educational Achievement Civic Education Study (CIVED 1971) ${ }^{1}$, CIVED $(1999)^{2}$, the 2009 International Civic and Citizenship Study (ICCS 2009) ${ }^{3}$, and more recently the 2016 ICCS $^{4}$ did not include post-genocide countries except Israel (in the first two studies). The present article aims to fill this gap. It critically investigates the citizenship concept at work in post-genocide Rwanda, with a specific focus on the Itorero scheme for HSLs. Educating young Rwandans for citizenship is of paramount importance. Drawing on Quaynor (2015), it can be argued that the future of the political landscape in Rwanda largely depends on how young people are taught and conceptualize the notion of being 'a good citizen'. In other words, the ways that young people understand and enact citizenship is likely to influence the political direction of Rwanda.

Secondly, formal citizenship education is manifest and popular in many African countries. However, it does not yield many noteworthy results (Mhlauli 2012; Harber 1997; Otiende and Oanda 2000). This is evidenced by intermittent tribal wars, the current weak popular understanding of democratic culture and institutions, and weak inclinations towards political involvement beyond voting in parliamentary or presidential elections (Torney-Purta, Lehmann, Oswald and Schulz 2001; Davies 2005; Quaynor 2015). It is argued that formal citizenship education in Africa is largely ineffective, owing to both the low priority that teachers give to the subject and the continued predominance of didactic, teacher-centred pedagogy (TorneyPurta et al. 2001; Neubauer 2012; Harrison and Baumgartl 2002). Formal citizenship education in post-genocide Rwanda is no exception (Freedman, Weinstein, Murphy and Longman 2008; King 2013).

Against this backdrop, several studies (e.g. Antal and Easton 2009; Ake 1996; Ogot 1999; Osaghae 2006; Neubauer 2012) have revealed that there is a need to revitalize African nonformal or indigenous citizenship education practices. The idea is that citizenship education in present-day Africa should draw on its cultural heritage and adapt its good practices to today's situation and demands. It is in this context that the post-genocide Rwanda revived its traditional citizenship education program, Itorero.

While there has been a strong commitment to build on African indigenous practices in citizenship education, little attention has been paid to the evaluation of their implementation. 
The present article also aims to fill this vacuum. It strives to assess the extent to which, if any, the Itorero training in post-genocide Rwanda specifically the scheme meant for HSLs avoids the problems of traditional African citizenship education practices, chief among which is indoctrination as opposed to reflective thinking (Adeyemi and Adeyinka 2003; Enslin and Horsthemke 2004).

The present study aims to reveal the strengths and weaknesses of traditional models in citizenship education. Furthermore, it is hoped that researchers, educationalists and policy makers will benefit from the findings of this study, particularly in relation to citizenship education practices in post-genocide contexts. This study hopes to contribute to the improvement of citizenship education of HSLs, which is crucial to the reconstruction process, social cohesion, and peace building in Rwanda.

The present study employs a mixed-method design involving: (i) a survey questionnaire coupled with focus group discussions with HSLs, and (ii) interviews with NIC officials and Itorero trainers. These instruments were found appropriate, because they allowed access to first hand information from people directly involved in the Itorero training.

The article is divided into the following four sections. The first section contains general considerations regarding citizenship and citizenship education. Secondly, the landscape of citizenship education in post-genocide Rwanda is outlined in a bid to locate the revival of Itorero, mainly in the scheme for HSLs. Thirdly, the conceptual framework and methodology guiding the study are articulated. The fourth section is dedicated to key findings and discussion.

\section{GENERAL CONSIDERATIONS REGARDING CITIZENSHIP}

Citizenship is a rather contested, ambiguous and complex concept (Riesenberg 1992; Wayne 2004; Oliver and Heater 1994; Ramphele 2001). Nonetheless, Carr (1991, 374) reminds us that contested concepts have an 'uncontested' common core by virtue of which they convey a certain message. This article employs the following working definition, which of course will be enriched in what follows: 'Citizenship is normally taken to mean the membership of and participation in the activities of a community or group communities' (Bailey 1998, 14). Citizenship has three dimensions: legal, political, and social (Marshall 1964; Phelan 2001; Osler and Starkey 2005). The legal dimension of citizenship has to do with rights, entitlements and privileges, like the right to vote, to stand for election, to own property, etc. The idea of citizenship also entails political participation. A citizen is expected to be relatively interested in what happens on the political scene and to have a stake in it. More importantly, citizenship signals a social identity. It conveys a feeling of being at home and a feeling of belonging to a 
community (Osler and Starkey 2005, 11; Staeheli and Hammet 2010, 673).

\section{CONSIDERATIONS REGARDING CITIZENSHIP EDUCATION}

In general terms, citizenship education can be understood as the transmission of knowledge, skills, values and attitudes that will enable young people to participate meaningfully in the community of which they are part locally, nationally, and globally (Arthur, Davies and Hahn 2008, 5-6). In terms of content, citizenship education usually covers areas such as 'national history, constitutions and political systems, citizen and human rights, international organizations and relations, economic and welfare, media, environmental issues, and civic virtues’ (Torney-Purta et al. 2001, 163).

With regard to its mode of delivery, citizenship education may be formal, non-formal or informal. Formal citizenship education is usually associated with certification and includes education and training in institutions like schools. It has a sequential curriculum and an established structure of assessment (Chioncel and Jansen 2004, 23). Formal citizenship education can be a specific subject; integrated with social science subjects; integrated across all subjects or an extra-curricular activity (Arthur, Davies and Hahn 2008, 489). On the other hand, non-formal citizenship education refers to all systematic or well-organized educational interventions outside the formal system. It is a kind of state intervention in post-school learning (Chioncel and Jansen 2004, 23). Informal citizenship education is defined as the unorganized, unsystematic, and/or unintended lifelong learning at home, work, and through the media (Chioncel and Jansen 2004, 23). This article focuses on non-formal citizenship education in post-genocide Rwanda particularly the Itorero training scheme meant for HSLs. The next section offers a brief discussion of the landscape of citizenship education in the context of postgenocide Rwanda.

\section{CITIZENSHIP EDUCATION IN POST-GENOCIDE RWANDA: FROM 1994}

\section{TO PRESENT}

The in-school and out-of-school citizenship education in post-genocide Rwanda expresses an emphatic preference for national identity, i.e. Rwandanness, over potentially divisive ethnic affiliations (Tutsi, Hutu, Twa). In primary school (Grade 1 to Grade 6), citizenship is called 'social studies' and taught in two lessons (Grade 1 to 3), and five lessons (Grade 4 to 6) per week, respectively. In high school, citizenship education is termed 'political education'. It is a compulsory but non-examinable subject with the weight of two lessons per week (Ministry of Education 2008). 
Although the out-of-school citizenship education is the concern of a number of institutions such as the National Unity and Reconciliation Commission (NURC), the Rwanda Demobilization and Reintegration Commission (RDRC), the National Electoral Commission (NEC) and the National Commission for the Fight against Genocide (Commission Nationale de Lutte contre le Génocide - CNLG), it is crucial to note that the National Itorero Commission (NIC) was established with the specific mandate, namely, to educate Rwandans for citizenship. In what follows, a discussion on the revived 'Itorero' is presented with a specific focus on the scheme meant for HSLs.

\section{Itorero teaching: The case for HSLs}

The traditional Itorero (before colonialism) focused primarily on military training and sport; it was a way of training a professional army. Secondary consideration was given to other domains of education such as moral (values and taboos of the Rwandan culture), political (vision and policies of the Rwandan kingdom), cultural (traditional songs and dances), and linguistics and literary education (poetry, debate and rhetoric) (Ndaruhutse 2008; Vansina 2004; Codère 1973; Maison des Jeunes de Kimisagara 2008).

In the revived Itorero, emphasis is placed on moral and political education. Concerning moral education, the NIC has defined seven key values that every Rwandan is expected to know and live by. These are Rwandanness, patriotism, integrity, courage, self-sacrifice, love for a well-done work, and upholding one's dignity. Taboos have also been defined and they include issues like shedding blood, inattention to result, avoidance of accountability, untrustworthiness, and being covetous, etc. (National Unity and Reconciliation Commission 2009, 12).

With regard to political education, the revived Itorero insists on the history of Rwanda and national development programs mainly Vision 2020, and Economic Development and Poverty Reduction Strategy I and II (EDPRS I and II). These programs are aimed at uplifting Rwanda from poverty to a middle income country by 2020. In relation to the history of Rwanda, the historiography depicted in Itorero makes a distinction between three periods: the precolonial Rwanda or 'Golden age'; the ‘dark age' (colonial rule: 1899-1962, first and second republics: from 1962 to 1994); and the 'renaissance' (1994 to present) (Sundberg 2014). While the training of other categories of Rwandans (e.g. artists, journalists, local leaders, etc.) is subject to available time and means, every year all HSLs are trained.

The Itorero training for HSLs comprises two phases. The first phase (which involves schooling in relevant theory) is dedicated to the Itorero core teaching described earlier: moral, political and cultural education. It takes three months and is concluded by an intensive four-day 
onsite training. The second phase is community service where HSLs after completing high school carry out various activities of public interest in areas, such as education, health, infrastructure, environment and conservation, safety and security, governance and leadership (National Itorero Commission 2011, 16). The present article focuses on the first phase, i.e. moral, political and cultural training as part of citizenship education.

\section{CONCEPTUAL FRAMEWORK}

The following five conceptions of citizenship and citizenship education are significant in the present study: civic republicanism, liberalism, communitarianism, cosmopolitanism, and radical democracy.

\section{The civic republican notion of citizenship and citizenship education}

For civic republicanism, a 'good citizen' is one who demonstrates a strong sense of active political participation or civic engagement, and selfless dedication to the good of the political community (Honohan 2002). Furthermore, according to this notion, the good of the public community takes precedence over private interests (Van Steenbergen 1994; Honohan 2002; Heater 2004; Sandel 1999), and individual rights are subordinate to one's duties and responsibilities (Heater 2004; Sandel 1999). Citizenship education, under civic republicanism, focuses on the transmission of civic virtues such as placing the public above the private, subordinating personal interests to the common good, and being courageous and patriotic. It also prioritizes discharging one’s duties over enjoying ones’ rights (Sandel 1999; Heater 2004).

The civic republican notion of citizenship and citizenship education has been criticized by various scholars. They say that it sacrifices individual rights (Mouffe 1992), ignores the private sphere as an important domain (Heater 2004) and is 'inherently oppressive, moralistic, exclusive, militaristic and masculinist' (Honohan 2002, 6). Despite its drawbacks, civic republicanism seems to represent a middle ground between liberalism and communitarianism (Van Steenbergen 1994; Honohan 2002) which are examined in the next sections.

\section{The liberal notion of citizenship and citizenship education}

In broad terms, liberalism is characterized by the following features: equality and individual freedom, acceptance of competing conceptions of the good, dualism between public and private spheres, neutrality of the state, and the rejection of the formative project, i.e. inculcating civic virtues in the youth (Walzer 1989, 211).

The liberal notion of citizenship acknowledges the values of the individual. It is with this 
notion that the rise of individual rights occurs and recognition of equality of all people gains significance. Liberalism also depicts the person as free from any conceptions of the good established by society or the state. As fundamentally free, the person has to define for herself the type of life which she judges to be worthwhile.

A number of studies (e.g. Sandel 1999; Kymlicka and Norman 1994; Tomasi 2001; Galston 1988) have suggested that when considering liberalism and citizenship education, it is essential to bear in mind the existence of two strands: procedural or anti-perfectionist liberalism, and perfectionist liberalism.

Procedural liberalism maintains that the smooth functioning of the polity does not necessarily rest on virtuous citizens (Sandel 1999, 211), and check and balance mechanisms would be enough to counteract oppression (Kymlicka and Norman 1994, 359). It is suggested that citizenship education amounts only to teaching young people how best to exercise their rights and discharge their duties (Tomasi 2001).

On the other hand, perfectionist liberalism believes that virtue is essential for the success of the polity (Kymlicka and Norman 1994; Galston 1989). It follows that citizenship education should instill in young people liberal virtues such as courage, law-abidance, loyalty, independence and tolerance (Galston 1988, 1281-1282), and public spiritedness or public reasonableness, a sense of justice, and civility (Kymlicka 1997, 1-6). It is crucial to note that procedural liberalism contrasts more sharply with civic republicanism than does perfectionist liberalism. In the present article, liberalism is understood mainly in the more common, procedural sense. Procedural liberalism has been challenged on several grounds: its conception of the person as separate from and prior to community, its acceptance of competing conceptions of the good, and the requirement of state neutrality (Mulhall and Swift 2007; Kartal 2002; Faulks 2000). The communitarian notion of citizenship is sometimes portrayed as an attempt to remedy the weaknesses of liberalism.

\section{The communitarian notion of citizenship and citizenship education}

The communitarian concept of citizenship relies fundamentally on the following elements: a conception of the person as a social being, the priority of the community over the individual, emphasis on the common good and on common perception of the 'good' (Sandel 1982; Mulhall and Swift 2007; Carney 1992; Van Steenbergen 1994; Etzioni 1993). Unlike liberalism, which perceives the person as an isolated self, privately modelling and pursuing her own conception of the 'good', communitarianism affirms that the person is part and parcel of the community from which she receives identity, self-understanding, the 'good' and values. This suggests that 
the liberal 'unencumbered self' (Mulhall and Swift 2007, 158) is replaced by the 'embedded self' (Carney 1992, 274).

Again unlike the liberal citizen who condones the dualism between the public and the private, communitarian citizens value the common good and common bonds to which they subordinate their self-interests. It is in this context that Sandel (1982) contends that liberalism (as individualism) is the politics of rights, while communitarianism is the politics of the common good. Different scholars (e.g. Arthur 1998; Avineri and De-Shalit 1992; Etzioni 1993) affirm that communitarianism places strong faith in citizenship education to ensure the wellbeing of society. Citizenship education should focus on the transmission of values that the community has defined as core to its survival (Arthur 1998, 362). A 'good citizen' is one who values the community and its ethos, and preserves the common good.

The communitarian notion has been criticized on the basis of overemphasizing the authority of the community. Some see it as inherently conservative (Avineri and De-Shalit 1992) while others argue that it is likely to lead to totalitarianism (Mulhall and Swift 2007). It has also been observed that communitarianism, through its emphasis on our attachment to community, places strong limits on individual freedom and autonomy (Arthur 1998).

\section{The cosmopolitan notion of citizenship and citizenship education}

Several studies (e.g. Waghid 2007; Gutmann 2002; Osler and Starkey 2005; 2003; Nussbaum 1994; Tuomi, Jacott and Lundgren 2008; Taylor 1989; Staeheli and Hammett 2010; Koutselini 2008; Davies 2005; Reilly and Niens 2014; Audi 2009; Heater 2004; Appiah 2008) have shown that the cosmopolitan notion of citizenship focuses on openness to the world, celebration of human diversity, recognition of our common humanity, and having a sense of solidarity with others. As Osler and Starkey (2005) argue, cosmopolitan citizenship is a way of looking at the world from a perspective that accepts that all human beings are equal in dignity and rights.

Cosmopolitan citizenship education strives to provide learners with knowledge, skills, values and dispositions for participating in the community at any level, i.e. local, national or global. For a cosmopolitan citizen to act locally, nationally, regionally and globally, Smith $(2007,46)$ maintains that certain virtues are required which includes the ability to step back from one's ties and commitments without disowning them; and developing a heightened feeling or care for the world. The cosmopolitan notion of citizenship has been criticized for undermining and diluting the very notion of citizenship. According to Miller (1998, 60), it does not have a real ground or a tangible concrete community. Another contention is that cosmopolitanism lacks a legal backing either in the natural law or positive law (Neff 1998). 


\section{The radical democratic notion of citizenship and citizenship education}

The radical democratic notion of citizenship understands citizenship in terms of strong political participation (Delanty 2000) and expansion of the terrain of the political (Isin and Turner 2002). It looks at political participation in terms of direct, grassroots activity whereby a citizen is to participate extensively with no intermediary. For this participation to be efficient, citizens must have good communication and deliberative skills. Furthermore, radical democracy advances the idea that all people should be integrated in politics, regardless of their differences.

Radical democratic citizenship education aims at imparting to learners knowledge, skills, values and dispositions towards strong political participation (Isin and Turner 2002; Gutmann 1996; Mouffe 1992), public deliberation (Waghid 2006; Benhabib 2002; Habermas 1994), and acceptance of differences based on gender, culture, ethnicity, nationality, race, sexual orientation and socioeconomic status (Abowitz and Harnish 2006; Kymlicka and Norman 1994; Phelan 2001; Young 1989).

The radical democratic idea of considering each group in politics has been severely criticised. A significant contention is that a good number of public matters necessitate special skills from experts, which the common demos or populace does not have. In this regard, Isin and Turner (2002) argue that radical democacry is inattentive to real and material power relationships.

The present research seeks to establish the extent to which the Rwanda's Itorero embraces ideas that relate to the aforementioned citizenship concepts. In what follows, the methodology guiding the present study is briefly discussed.

\section{METHODOLOGY}

The present article follows the mixed method design. It is a quantitative-qualitative study that engaged with three categories of participants: (i) HSLs who underwent the Itorero training mostly in 2013 and were in level one in 2015 at private and public higher learning institutions in Rwanda; (ii) Itorero district trainers; and (iii) NIC officials. A total of 996 HSLs responded to the survey questionnaire while 19 HSLs participated in four focus group discussions. In addition, four interviews with district trainers and three with NIC officials were conducted. The data collection took place in Rwanda from November 2014 through March 2015. The questionnaire for HSLs is in the appendices.

In order to investigate the citizenship notion informing the Itorero training, its graduates, i.e. HSLs were presented with a list of 21 items describing a 'good citizen' ${ }^{5}$ Using a four-point 
Likert scale ( 1 = strongly disagree, 2 = disagree, 3 = agree, 4 = strongly agree) HSLs were to indicate the extent to which they agree with the idea that suggested items coincide with the image of a 'good citizen' fostered by Itorero teaching. These items were drawn from the five citizenship notions constituting the conceptual framework. Civic republicanism generated four items: placing public interests above private ones; fulfilling one's duties and responsibilities; being loyal to the state; and serving in the military. Liberalism contributed the four following items: pursuing one's private interests; enjoying one's rights and privileges; obeying the law; and having the ability to question ideas.

Communitarianism provided five items: being a role model; respecting core values of one's community; preserving the community's common good; putting the national identity above all other identities; and reducing social inequalities. Cosmopolitanism contributed the four following items: viewing oneself as a member of the world community; fighting human rights violations locally; fighting human rights violations globally; and protecting the environment. Radical democracy contributed four items: participating actively in politics; respecting minority groups; joining a political party; and participating in elections.

For reliability purposes, the questionnaire for HSLs was subjected to Cronbach's Alpha test. The obtained reliability is .73, which is a good score given that the standard is .60 and above. As for validity, Principal Component Analysis (PCA) and Confirmatory Factor Analysis (CFA) were conducted on the 21 items depicting a 'good citizen'.

PCA was performed using SPSS 22 and CFA was done by means of AMOS 22. The end result of PCA and CFA was four scales with a good fit with the data: the goodness-of-fit index (GFI) is .97; the comparative fit index (CFI) is .93; and the root mean square error of approximation (RMSEA) is .039. The obtained goodness-of-fit is acceptable, although the CFI is slightly below the standard (.95). The PCA output and the CFA model are in the appendices.

\section{RESULTS: THE DOMINANT CITIZENSHIP NOTION IN THE ITORERO TRAINING}

The extent to which each scale is recognized (by HSLs) as informing the Itorero training is provided in Table 1.

Table 1: Descriptive statistics for scales describing a 'good citizen'

\begin{tabular}{|l|l|l|l|l|l|}
\hline Scale & Mean & SD & Min. & Max. & Skewness \\
\hline 1. Civic republican/communitarian citizen & 17.42 & 1.99 & 9 & 20 & -.76 \\
\hline 2. Cosmopolitan citizen & 17.38 & 2.23 & 7 & 20 & -1.08 \\
\hline 3. Conventional democratic citizen & 10.45 & 2.58 & 2 & 16 & -.16 \\
\hline 4. Liberal citizen & 8.47 & 1.91 & 2 & 12 & -.31 \\
\hline
\end{tabular}

Source: Primary Data 
As can be seen in Table 1, the civic republican/communitarian scale receives greater recognition than other scales. Its mean is 17.41 (SD = 1.99), with scores ranging between 9 and 20. The scale ‘civic republican/communitarian' comprises the following attributes of a 'good citizen': obeying the law; being loyal to the state; preserving the community's common good; being the role model; and respecting community's core values. The implication of this finding is that, according to HSLs, the Itorero training teaches them that a 'good citizen' is one who (i) obeys the law; (ii) is loyal to the state; (iii) preserves the community's common good; (iv) is a role model; and (v) respects the community's core values. It is crucial to note that PCA and CFA suggested some surprising collapsing of civic republicanism and communitarianism.

Results indicate that the cosmopolitan notion comes in second place in informing the Itorero training with a mean of 17.38 (SD $=2.23)$, with scores ranging between 7 and 20 . It encompasses characteristics like fighting human rights violations globally; fighting human rights violations locally; protecting the environment; reducing social inequalities; and respecting minority groups. In the third place comes the conventional democratic notion, with a mean of $10.45(\mathrm{SD}=2.58)$; its minimum and maximum scores are 2 and 16 , respectively. The liberal notion of citizenship is ranked last, with a mean of 8.47 (SD =1.91), the minimum score of 2 and the maximum score of 12 .

Overall, these results lead to the conclusion that according to HSLs, although the Itorero training engages with a variety of citizenship notions, it is strongly committed to the civic republican/communitarian concepts of citizenship. The present research investigates whether such a ranking varies within subgroups. To this effect, parametric inferential techniques (independent t-Test and ANOVA) were used given the assumption of normality and homogeneity of variance.

In terms of gender, a statistically significant difference was found between males and females in their rating of the conventional democratic notion of citizenship: t988 $_{98}=-3.026$ where $p=.003$. However, the effect size is small (Cohen's D score $=0.19$ ). Indeed, female respondents favoured the conventional democratic notion slightly more than male respondents. Their respective means are $1.70(\mathrm{SD}=2.53)$ and $1.20(\mathrm{SD}=2.60)$. In relation to marital status, age, and training periods, no statistically significant difference was found within subgroups in rating citizenship notions.

These inferential results suggest that, in general, HSLs describe the image of a 'good citizen' endorsed by Itorero training nearly in the same way regardless of their gender, marital status, age, and training period. The implication of this finding goes as follows: the conclusion 
that the Itorero training scheme for HSLs is strongly committed to the civic republican/communitarian notions does not vary according to subgroups; it cuts across subgroups. This conclusion is supported by results from focus group discussions with HSLs, and results from interviews with both trainers and NIC officials.

\section{Evidence 1: Focus group discussion results with HSLs}

HSLs were asked to tell briefly how they would describe a 'good citizen' based on the teaching they received in the Itorero training. The following is an exemplary opinion:

According to the Itorero teaching, a 'good citizen' is one who loves the country. Loving the country at all times, this was constantly emphasized. A 'good citizen' loves the country and is ready to fight and defend it in case its security is at stake. I remember at one time they [the trainers] put to us a saying that 'you refuse your blood to the country, and dogs eat it up without pay'. The idea is that you may refuse to fight for your country and later you die shamefully in a foreign land. Your blood which you refused for your country is still lost. We were also told that 'good citizens' help each other ... [P11]

\section{Evidence 2: Interviews with Itorero district trainers}

Itorero district trainers were requested to describe in a few words the image of a 'good citizen' they communicate to HSLs. Here is one of the answers:

Before I go any further, there is a slogan which we use most frequently and which could help you understand the image of a 'good citizen' we communicate. This slogan reads as follows: 'I am an authentic Rwandan who loves her country and countrymen, strives for self-reliance, and upholds her dignity'. Do you understand who an authentic Rwandan is? The teaching we provide to HSLs is primarily meant to allow them to have the value of loving the country. When you love your country, by implication you love its inhabitants; the country is nothing rather than its people ... [P51]

\section{Evidence 3: Interviews with NIC officials}

Regarding the question whether, according to NIC officials, the civic republican and communitarian notions of citizenship would inform the Itorero training for HSLs, the answer is very positive, as is apparent in the following view:

We teach that a 'good Rwandan citizen' is one who has values and taboos of the Rwandan culture and lives up to them. This allows her to love the country and its people. Second, it is someone who is happy about the way she is treated by the country. In response, she is ready to sacrifice herself for the country, and if the situation demands that, she is ready to fight and die for it. [P62]

Upon close scrutiny of some of the views of HSLs, trainers, and NIC officials, one is led to conclude that they depict 'good citizenship' along civic republican and communitarian 
concepts, given the relative emphasis placed on patriotism, self-sacrifice, respect for community's core values, and dedication to the common good.

\section{DISCUSSION}

\section{Are the civic republican/communitarian citizenship notions appropriate and indeed desirable for post-genocide Rwanda?}

The civic republican aspect is examined first in this section. Findings from the present study reveal that relying heavily on the civic republican paradigm renders the Itorero training scheme prey to civic republican pitfalls such as those elaborated by Honohan (2002) and Heater (2004). These include sacrificing individual rights (Itorero emphasises patriotism and self-sacrifice) and the risk of indoctrination and fanaticism (consider teaching about and recruiting members for the ruling political party, i.e. the Rwanda Patriotic Front - RPF - during Itorero training). These points will be elaborated on later. Besides, due to heavy dependence on the civic republican notion, the Itorero training scheme for HSLs tends to be moralistic (in reference to the established list of values to be taught and taboos to be avoided), militaristic (military exercises are empasized, e.g. parade and drill), and masculinist (female participants find some physical exercises done in the Itorero training beyond their capacity). Among the above mentioned problems, the risks of indoctrination and fanaticism deserve particular attention.

One of the surprising results to emerge from focus group discussions with HSLs is that while Itorero has got a mandate to 'bring up a patriotic Rwandan who has values and taboos of the Rwandan culture and who has the culture of Intore' (Law $N^{\circ} 41 / 2013$ of 16/06/2013, determining the NIC's mission, organization and functioning, article 6), it is being diverted into a forum to teach about and recruit members for the ruling political party - the RPF. Findings from the present study show that, nearly all informants (HSLs), agree that in their training sites lessons on the RPF are provided, and interested HSLs are encouraged to take an oath of allegiance to the ruling party. Hence, one of the HSLs says:

I knew and had heard about the RPF. But it is particularly in the Itorero training that I received substantial instructions, following which I came to have a better understanding of its principles. [P32]

However, nearly all participants seem to agree that joining the RPF is done on a 'voluntary basis'; they appear to be convinced that there is no use of force or direct coercion. One informant explains this in the following terms: 
Nobody forced me at all to join the RPF. There is a common saying used by our leaders that 'results speak for themselves'. In view of this, after seeing all achievements that Rwanda recorded thanks to the RPF, and after being informed of how far we have come .... I joined the RPF on my own, nobody compelled me to do so. [P23]

That the Itorero training for HSLs is partly an instrument for the ruling party to teach its driving ideology and recruit members is also affirmed by a vast majority of Itorero trainers. Two examples follow:

Yes, on our site, trainees [HSLs] were given a talk about how the RPF delivered the country from the hands of killers. At the same occasion, RPF principles were explained; and HSLs were shown the progress so far made thanks to RPF leadership. At the end of the talk, interested trainees were asked to become members of the RPF and take the oath of allegiance. A good number of HSLs joined and took the oath of allegiance to the RPF, but nobody was forced to do so. [P54]

During the Itorero training for HSLs, because we have got powers to do so - by the way, I do not see any reason as to why we [trainers] should not do it - we provided HSLs with direct instructions about the RPF. At the end, a huge number of them became members. This activity was facilitated by the officials of the sector [Umurenge]. It was done in the evening recreation. [P53]

One NIC official also underscored the fact that the Itorero training does teach about the RPF and recruits its members from the centers:

We teach them about patriotism; we tell them about the RPF and its main good principles. Later, HSLs, on their own, request to be members of the RPF. Therefore, we say 'okay, let those interested to join the RPF come'. But nobody is forced to join the RPF, it is not good to compel someone become a member of a particular political organization. This would be bad. [P62]

The suggestion that HSLs join the RPF on their own and take the oath of allegiance voluntarily is rather dubious. What is interesting is that some NIC officials deny categorically that Itorero provides instruction on and recruits for the RPF. Consider the following defensive reaction from a concerned NIC official:

It is not possible. Teaching about the RPF is not on the training program produced by the NIC, which program ought to be followed by all training sites ... Nobody told me that someone came and stopped the program with the intention to instruct HSLs about the RPF. Unless they [the trainers] organize themselves to do this during the time meant for sport activities ... But that agenda is not known ... That is not part of the mandate entrusted to Itorero by the government. [P61]

It is interesting to note that these claims clearly contradict views of HSLs and even some district trainers, who confess that instruction on and recruitment for the RPF is done among HSLs 
undergoing Itorero training. HSLs and trainers seem to be correct in saying that the Itorero training for HSLs does teach about and recruits members for the ruling party - the RPF. As indicated earlier, even one NIC official confessed that the RPF recruits from Itorero.

The issue of teaching about the RPF and recruiting its members in the course of the Itorero training for HSLs raises serious concerns and deserves to be addressed with great care. Obviously, worries are rife about what might be seen as malpractice or mis-education. One can rightly ask the following questions: (i) Is this citizenship education? On whose mandate do Itorero trainers teach about and recruit for the RPF? Could it be an excess of zeal? If so, would it be an acceptable mechanism of recruitment? (ii) To what extent are HSLs free in joining the RPF during the Itorero training? (iii) To what extent does this practice differ from indoctrination and other forms of mis-education, and indeed fanaticism? Answering these questions in an even handed manner requires further investigation, which is beyond the scope of the present study. Suffice it to say at this point in time that this practice is likely to lead to indoctrination and fanaticism, which are also incidentally the outcomes of relying heavily on the civic republican model of citizenship education.

Another restraining force in the Itorero training scheme for HSLs is its overreliance on communitarianism, which has its own limitations. As outlined in the conceptual framework, the communitarian paradigm is criticized for overemphasizing the authority of the community. While some take it as very conservative (Avineri and De-Shalit 1992), others maintain that it places strong limits on individual freedom and autonomy (Arthur 1998). The Itorero training scheme for HSLs is vulnerable to the critique that is conservative and that it limits individual freedom and autonomy. It displays conservatism, particularly because it establishes the list of values to be followed and taboos to be avoided. It sets limits to the autonomy and freedom of trainees because the latter do not have a say in the definition of those values and taboos. From the findings of the present study, it remains unclear as to how the Itorero training can avoid these communitarian pitfalls.

In short, the present research indicates that the civic republican/communitarian model as it is applied in Rwanda - is limited precisely because it tends to conflate 'good citizenship' and unquestioning patriotism, blind loyalty and uncritical obedience to the ruling political party. In this regard, findings from the present study confirm and extend other studies (e.g. Sundberg 2014; Turner 2014; Purdekovà 2011; Mgbako 2005) conducted on Itorero and its parent Ingando. By scrutinizing closely the two platforms, these studies reveal that (i) majority of participants in Itorero were requested to join the ruling political party, the RPF, and hence, it is not wide of the mark to argue that Itorero partly serves as a forum for manufacturing citizens 
according to the RPF ideology (Sundberg 2014); (ii) Itorero aims to allow the RPF win the minds and hearts of the population it liberated (Turner 2014, 424); and (iii) Itorero and Ingando teaching portray an ideal citizen as a 'person with obligations rather than a rightful person' (Purdekovà 2011, 45) and 'RPF loyalist' (Mgbako 2005, 217).

Nonetheless, inspite of the above mentioned weaknesses, the present article notes that the Itorero training scheme for HSLs has some advantages. Firstly, it fosters Rwandanness which militates against emphasis on potentially divisive ethnic affiliations. The following is exemplary of the opinions of HSLs in this regard:

In our homes, we still hear so many things from our fathers, mothers and guardians. Some of the latter tell that Rwandans are not one - as it is upheld today; they teach that tall people with a sharp nose are Tutsi; short ones with a bold nose are Hutu. Besides, more often than not, we have been instructed not to visit certain families nor interact with their children. It is true; our parents have told us many things, some of which are detrimental to the unity of Rwandans. In this context, if one does not get a chance to undergo the Itorero training and learn that we are one as Rwandans, mostly likely one will grow up guided by those thwarted stereotypes. The Itorero training has set our minds free from bad ethnic ideologies received from our parents. [P12]

The authors concur with a central aspect of Itorero teaching and with Shyaka's (2003) observation that a 'good Rwandan citizen' would be one who puts the Rwandan identity before and above all other identities. Secondly, it is quite uncontroversial that some qualities of a 'good citizen' emphasized by Itorero teaching are worth pursuing. Reference is made here to attributes such as courage, integrity, working hard and working well, being self-reliant, and defending one’s dignity. Thirdly, it is surely beyond doubt that Itorero teaching acquaints HSLs with some values, sensibilities and taboos of the Rwandan culture, the history of Rwanda, and current national development programs and policies, mainly Vision 2020 and EDPRS I and II.

\section{CONCLUSION}

This study has shown that the Itorero training scheme for HSLs is robustly committed to the civic republican/communitarian notions of citizenship; it is committed to some extent to the cosmopolitan notion of citizenship; it works to a limited extent with the conventional democratic notion; and it engages, to a very limited extent, with the liberal notion of citizenship. Some of the challenges that emerge from the overreliance on civic republican/communitarian notions have been highlighted with specific reference to indoctrination and fanaticism. It has been demonstrated that the civic republican/communitarian paradigm as practiced in postgenocide Rwanda is likely to produce blind patriotism, unqualified loyalty and uncritical obedience to the ruling party under the veil of 'good citizenship'. 
However, the Itorero training can be commended for fostering Rwandanness rather than potentially divisive ethnic affiliations; promoting courage, integrity, working hard and working well, being self-reliant, and upholding one's dignity; and sensitising HSLs to values and sensibilities of the Rwandan culture, the history of Rwanda, and current national development programs and policies. In sum, the present article accounts for the strengths and limitations of a non-formal traditional training programme (Itorero) that inducts youth in citizenship education.

\section{ACKNOWLEDGMENTS}

This research was financially supported by DFID through the Research, Policy and Higher Education (RPHE) programme at Aegis Trust Rwanda. Opinions expressed and conclusions arrived at are those of the authors and are not necessarily to be attributed to the Aegis Trust.

\section{NOTE}

1. For details on findings of CIVED (1971) see (i) Torney, Oppenheim and Farnen (1975); and (ii) Walker (1976).

2. In relation to results from the CIVED (1999) see (i) Torney-Purta, Lehmann, Oswald and Schulz (2001); and (ii) Amadeo, Torney-Purta, Lehmann, Husfeldt and Nikolova (2002).

3. Concerning findings of the ICCS (2009) see Schulz, Ainley, Fraillon, Kerr and Losito (2010).

4. With regard to ICCS (2016) see Schulz, Ainley, Fraillon, Losito and Agrusti (2016).

5. The purpose of the study is not to assess the impact of Itorero training on HSLs; rather, what is at issue here is to investigate the image of a 'good citizen' being fostered by Itorero training.

\section{REFERENCES}

Abowitz, K. K. and J. Harnish. 2006. Contemporary discourses of citizenship. Review of Educational Research 76(4): 653-690.

Adejumobi, S. 2001. Citizenship, rights and the problem of conflicts and civil wars in Africa. Human Rights Quarterly 23: 148-170.

Adeyemi, M. B. and A. A. Adeyinka. 2003. The principles and content of African traditional education. Educational Philosophy and Theory 35(4): 425-440.

Ake, C. 1996. Rethinking African democracy. In The global resurgence of democracy, ed. L. Diamond and M. Plattner, 63-75. Baltimore: Johns Hopkins University Press.

Amadeo, J., J. Torney-Purta, R. Lehmann, V. Husfeldt and R. Nikolova, R. 2002. Civic knowledge and engagement: An IEA study of upper secondary students in sixteen countries. Amsterdam: IEA.

Antal, C. and P. Easton. 2009. Indigenizing civic education in Africa: Experience in Madagascar and the Sahel. International Journal of Educational Development 29: 599-611.

Appiah, K. A. 2008. Education for global citizenship. Yearbook of the National Society for the Study of Education 107(1): 83-99.

Arthur, J. 1998. Communitarianism: What are the implications for education? Education Studies 24(3): 353-368.

Arthur, J., I. Davies and C. Hahn. (Eds.). 2008. The SAGE handbook of education for citizenship and democracy. London: SAGE. 
Audi, R. 2009. Nationalism, patriotism, and cosmopolitanism in an age of globalization. The Journal of Ethics 13(4): 365-381.

Avineri, S. and A. De-Shalit. (Eds.). 1992. Communitarianism and individualism.Oxford: Oxford University Press.

Bailey, R. 1998. Teaching values and citizenship across the curriculum. Glasgow: Kogan Page Limited.

Benhabib, S. 2002. The claims of culture: Equality and diversity in the global era. Princeton, NJ: Princeton University Press.

Carney, S. 1992. Liberalism and communitarianism. A misconceived debate. Political Studies 40: 273289.

Carr, D. 1991. Educating the virtues. An essay on the philosophical psychology of moral development and education. London and New York: Routledge.

Chioncel, N. and T. Jansen. 2004. Reviewing education and training for governance and active citizenship in Europe - A central and eastern European perspective. Project RE-ETGACE.

Codère, H. 1973. The biography of an African society, Rwanda 1900-1960.Tervuren: Musée Royal de l'Afrique Centrale.

Davies, L. 2005. Teaching about conflict through citizenship education. International Journal of Citizenship and Teacher Education 1(2): 17-34.

Delanty, G. 2000. Citizenship in a global age. Society, culture, politics. Buckingham: Open University Press.

Enslin, P. and K. Horsthemke. 2004. Can Ubuntu provide a model for citizenship education in African democracies? Comparative Education 40(4): 545-558.

Etzioni, A. 1993. The spirit of community: Rights, responsibilities and the communitarian agenda. New York: Crown.

Faulks, K. 2000. Citizenship. London: Routledge.

Freedman, S. W., H. M. Weinstein, K. Murphy and T. Longman. 2008. Teaching history after identity based conflicts: The Rwanda experience. Comparative Education Review 52(4): 663-690.

Galston, A. W. 1988. Liberal virtues. The American Political Science Review 82(4): 1277-1290.

Galston, W. 1989. Civic education in the liberal state. In Liberalism and the moral life, ed. N. L. Rosenblum, 71-88. Cambridge, MA: Harvard University Press.

GoR see Government of Rwanda.

Government of Rwanda. 2013. Law N $\mathrm{N}^{\circ} 41 / 2013$ of 16/06/2013 establishing the National Itorero Commission and determining its mission, organization and functioning, Rwanda Official Gazette $\mathrm{N}^{\circ} 29$ of 22 July 2013.

Gutmann, A. 1996. Democratic citizenship. In For love of country: Debating the limits of patriotism, ed. J. Cohen, 66-71. Boston: Beacon Press.

Gutmann, A. 2002. Civic minimalism, cosmopolitanism, and patriotism: Where does democratic education stand in relation to each? Nomos 43: 23-57.

Habermas, J. 1994. Three normative models of democracy. Constellations 1(1): 1-10.

Harber, C. 1997. Education, democracy and political development in Africa. Brighton: Sussex Academic Press.

Harrisson, C. and B. Baumgartl. 2002. Stocktaking research on policies on education for democratic citizenship and management of diversity in South-East Europe. Regional analysis and intervention proposals. Council of Europe, GIV/EDU/CIT (2001) 45, Final Regional Report.

Heater, D. 1990. Citizenship: The civic ideal in world history, politics and education. London: Longman.

Heater, D. 2004. A brief history of citizenship. New York: New York University Press. 
Honohan, I. 2002. Civic Republicanism. Oxfordshire: Taylor and Francis.

Isin, E. F. and B. S. Turner, eds. 2002. Handbook of citizenship studies. London: Sage.

Kabwete Mulinda, C. 2002. La généalogie de l’idée du peuplement du Rwanda: considérations sur l'autochtonie ou l'allochtonie des Rwandais (The genealogy of the idea of settlement in Rwanda: Considerations on indigenousness or allochthony of Rwandans). In Peuplement du Rwanda. Enjeux et perspectives (People's settlement in Rwanda: Challenges and prospects), ed. F. Rutembesa, E. Ntaganda and J. Murwanashyaka, 49-72. Butare: Editions de l’Université Nationale du Rwanda.

Kartal, F. 2002. Liberal and republican conceptualizations of citizenship: A theoretical inquiry. Turkish Public Administration Annual 27-28: 101-130.

King, E. 2013. From classrooms to conflict in Rwanda. Cambridge: Cambridge University Press.

Koutselini, M. 2008. Citizenship education in context: Student teacher perceptions of citizenship in Cyprus. Intercultural Education 19(2): 163-175.

Kymlicka, W. 1997. Education for citizenship. Political Science Series 40: 1-25.

Kymlicka, W. and W. Norman. 1994. Return of the citizen: A survey of recent work on citizenship theory. Ethics 104(2): 352-381.

Maison des Jeunes de Kimisagara. 2008. Rapport de la recherche sur l'ecole traditionnelle du Rwanda (Itorero) (Report of a Research on the Rwandan traditional school (Itorero)). Kigali: Maison des Jeunes de Kimisagara.

Marshall, T. H. 1964. Class, citizenship and social development. New York: Doubleday \& Company, Inc.

Mgbako, C. 2005. Ingando solidarity camps: Reconciliation and political indoctrination in postgenocide Rwanda. Harvard Human Rights Journal 18: 201-224.

Mhlauli, M. V. 2012. The role of education on citizenship development in Africa. British Journal of Arts and Social Sciences 4(1): 104-115.

Miller, D. 1998. Bounded Citizenship. In Cosmopolitan citizenship, ed. K. Hutchings and R. Dannreuther, 60-80. London: Macmillan.

Ministry of Education. 2008. Social Studies Curriculum, Grade 1-6. Kigali, Rwanda.

Mouffe, C. 1992. Citizenship and political identity. The Identity in Question 61: 28-32.

Mulhall, S. and A. Swift. 2007. Liberals and communitarians. Oxford: Blackwell Publishing.

National Itorero Commission (NIC). 2011. National Itorero Commission Strategy. Kigali: NIC.

National Itorero Commission (NIC). 2012. Volunteerism Policy Paper. Kigali: NIC.

National Unity and Reconciliation Commission (NURC). 2009. Itorero ry'Igihugu (national Itorero). Policy note and strategic plan. Kigali : NIC.

Ndaruhutse, E. 2008. Les compagnies 'Amatorero' au Rwanda ancien et contemporain ('Amatorero' camps in ancient and contemporary Rwanda). Mémoire de Licence, Kigali Institute of Education.

Neff, S. 1998. International law and the critique of cosmopolitan citizenship. In Cosmopolitan citizenship, ed. K. Hutchings and R. Dannreuther, 105-119. London: Macmillan.

Neubauer, T. 2012. A critical review of international studies into citizenship and citizenship education - Lessons for citizenship education in Slovenia. Journal of Social Science Education 11(1): 81102.

Nussbaum, C. 1994. Patriotism and cosmopolitanism. Boston Review 19(5): 3-34.

Ogot, B. A. 1999. Building on the indigenous: Selected essays 1981-1988. Kisumu: Anyange Press.

Oliver, D. and D. Heater. 1994. The foundations of citizenship. Hertfordshire: Harvester Wheatsheaf.

Osaghae, E. E. 2006. Colonialism and civil society in Africa. The perspective of Ekeh's two publics. Voluntas 17: 233-245. 
Osler, A. and H. Starkey. 2003. Learning for cosmopolitan citizenship: Theoretical debates and young people's experiences. Educational Review 55(3): 243-254.

Osler, A. and H. Starkey. 2005. Changing citizenship. Democracy and inclusion in education. New York: Open University Press.

Otiende, J. E. and O. Oanda. 2000. Social studies in Kenya. In Social studies in African education, ed. M. B. Adeyemi, 205-215. Gaborone: Pyramid.

Phelan, S. 2001. Sexual strangers: Gays, lesbians and dilemmas of citizenship. Philadelphia: Temple University Press.

Prunier, G. 1995. The Rwanda crisis. History of a genocide. Columbia University Press.

Purdekovà, A. 2011. Rwanda's Ingando camps: Liminality and the reproduction of power (No. 80). Refugee Studies Centre, Working Paper.

Quaynor, L. J. 2015. Researching citizenship education in Africa: Considerations from Ghana and Liberia. Research in Comparative and International Education 10(1): 120-134.

Ramphele, M. 2001. Citizenship challenges for South Africa's young democracy. Daedalus 130(1): 117.

Reilly, J. and U. Niens. 2014. Global citizenship as education for peacebuilding in a divided society: Structural and contextual constraints on the development of critical dialogic discourse in schools. Compare: A Journal of Comparative and International Education 44(1): 53-76.

Riesenberg, P. 1992. Citizenship in the western tradition: Plato to Rousseau. Chapel Hill: University of North Carolina Press.

Sandel, M. J. 1982. Liberalism and the limits of justice. Cambridge: Cambridge University Press.

Sandel, M. J. 1999. Liberalism and republicanism: Friends or foes? The Review of Politics 61(2): 209214.

Schulz, W., J. Ainley, J. Fraillon,B. Losito and G. Agrusti. 2016. IEA International Civic and Citizenship Education Study 2016 Assessment Framework. Cham: Springer.

Schulz, W., J. Ainley, J. Fraillon, D. Kerr and B. Losito. 2010. ICCS 2009 international report: Civic knowledge, attitudes and engagement among lower secondary school students in thirty-eight countries. Amsterdam: IEA Secretariat.

Shyaka, A. 2003. Refondation de la rwandité: Stratégie de résolution des conflits, de démocratisation et de développement durable du Rwanda (Regrounding rwandanness: Strategy for conflict resolution, democratization and sustainable development). In Rwanda: Identité et citoyenneté, ed. F. Rutembesa, J. Semujanga and A. Shyaka, 206-219. (Rwanda: Identity and citizenship). Kigali: Pallotti-Presse.

Smith, W. 2007. Cosmopolitan citizenship: Virtue, irony and worldliness. European Journal of Social Theory 10(1): 37-52.

Staeheli, L. A. and D. Hammett. 2010. Educating the new national citizen: Education, political subjectivity and divided societies. Citizenship Studies 14(6): 667-680.

Sundberg, M. 2014. Training for model citizenship: An ethnography of civic education and state-making in Rwanda. PhD Thesis, Uppsala University.

Taylor, C. 1989. Sources of the self: The making of the modern identity. Melbourne: Cambridge University Press.

Tomasi, J. 2001. Liberalism beyond justice: Citizens, society and the boundaries of political theory. Princeton: Princeton University Press.

Torney, J. V., A. N. Oppenheim and R. F. Farnen. 1975. Civic education in ten countries: An empirical study. Stockholm/New York: Almqvist \& Wiksell International/John Wiley and Sons.

Torney-Purta, J., R. Lehmann, H. Oswald and W. Schulz. 2001. Citizenship and education in twentyeight countries: Civic knowledge and engagement at age fourteen. Amsterdam: IEA.

Tuomi, M. T., L. Jacott and U. Lundgren. 2008. Education for world citizenship: Preparing students 
to be agents of social change. CiCe Thematic Network Project.

Turner, S. 2014. Making good citizens from bad life in post egocide Rwanda. Development and Change 45(3): 415-433.

Van Steenbergen, B. 1994. The condition of citizenship. London: Sage Publications.

Vansina, J. 2004. Antecedents to modern Rwanda: The Nyiginya kingdom. Madison: University of Wisconsin Press.

Vogel, U. and M. Moran. 1991. The frontiers of citizenship. New York: St. Martin’s Press.

Waghid, Y. 2006. Deliberation and citizenship: Closing some of the gaps related to the 'Values in Education’ initiative in South Africa. South African Journal of Education 24(4): 278-283.

Waghid, Y. 2007. Educating for democratic citizenship and cosmopolitanism. South African Journal of Higher Education 21(5): 584-595.

Walker, D. A. 1976. The IEA Six Subject Survey: An empirical study of education in twenty-one countries. Stockholm/New York: Almqvist \& Wiksell International/John Wiley and Sons.

Walzer, M. 1989. Citizenship. In Political innovation and conceptual change, ed. T. Ball, J. Farr, R. L. Hanson, 211-220. Cambridge: Cambridge University Press.

Wayne, R. E. 2004. Negotiating the politics of citizenship education. Political Science and Politics 37(2): 249-251.

Young, I. M. 1989. Polity and group difference: A critique of the ideal of universal citizenship. Ethics 99: 250-274. 


\section{Appendix 1: Questionnaire for HSLs}

Name of the University:

Gender: Male

Female $\square$

Age:

Marital status: Single

Married $\square$

I underwent Itorero training in the year

I was trained in the Sector

District

Province

Question 1: Based on the instructions you received during Itorero training, which of the following statements best describes being a good citizen - a good Rwandan? Use the following scale to express your opinion (Tick $\sqrt{ }$ ):

\begin{tabular}{|l|l|l|l|}
\hline 1 = Strongly disagree & $2=$ Disagree & $3=$ Agree & $4=$ Strongly agree \\
\hline
\end{tabular}

\begin{tabular}{|l|c|c|c|c|}
\hline $\begin{array}{l}\text { I was taught that being a good citizen - a good } \\
\text { Rwandan - involves: }\end{array}$ & $\begin{array}{l}\text { Strongly } \\
\text { disagree }\end{array}$ & Disagree & Agree & $\begin{array}{l}\text { Strongly } \\
\text { agree }\end{array}$ \\
\hline 1. Placing public interests above private ones. & 1 & 2 & 3 & 4 \\
\hline 2. Fulfilling one's duties and responsibilities. & 1 & 2 & 3 & 4 \\
\hline 3. Being loyal to the state. & 1 & 2 & 3 & 4 \\
\hline 4. Serving in the military. & 1 & 2 & 3 & 4 \\
\hline 5. Being the role model. & 1 & 2 & 3 & 4 \\
\hline 6. Respecting core values of one's community. & 1 & 2 & 3 & 4 \\
\hline 7. Preserving the community's common good. & 1 & 2 & 3 & 4 \\
\hline 8. Putting the national identity above all other & 1 & 2 & 3 & 4 \\
identities or affiliations. & & & & \\
\hline 9. Improving the welfare of those in need. & 1 & 2 & 3 & 4 \\
\hline 10. Pursuing only and always one's private interests. & 1 & 2 & 3 & 4 \\
\hline 11. Enjoying one's rights and privileges. & 1 & 2 & 3 & 4 \\
\hline 12. Obeying the law. & 1 & 2 & 3 & 4 \\
\hline 13. Having the ability to question ideas. & 1 & 2 & 3 & 4 \\
\hline 14. Viewing oneself as a member of the world \\
community.
\end{tabular}


Appendix 2: The four-factor structure on the description of a good citizen

Factor 1: Cosmopolitan citizen

Loadings

\begin{tabular}{|ll|l|}
\hline 1. & Fighting human rights violations globally & .66 \\
\hline 2. & Fighting human rights violations locally & .63 \\
\hline 3. & Protecting the environment & .52 \\
\hline 4. & Reducing social inequalities & .48 \\
\hline 5. & Respecting minority groups & .45 \\
\hline
\end{tabular}

Factor 2: Conventional democratic citizen

\section{Loadings}

1. Joining a political party

2. Participating in all elections

.73

3. Participating in politics

4. Serving in the military

.57

.54

.46

Factor 3: Civic republican/communitarian citizen

Loadings

1. Obeying the law

2. Being loyal to the state

3. Preserving the community's common good

4. Being the role mode

5. Respecting community's core values

.44

.44

42

.36

Factor 4: Liberal citizen

Loadings

\begin{tabular}{|c|c|}
\hline 1. Questioning ideas & .30 \\
\hline 2. Enjoying one's rights and privileges & .58 \\
\hline 3. Being a member of the world community & .42 \\
\hline
\end{tabular}


Appendix 3: The four-factor CFA model on the description of a good citizen

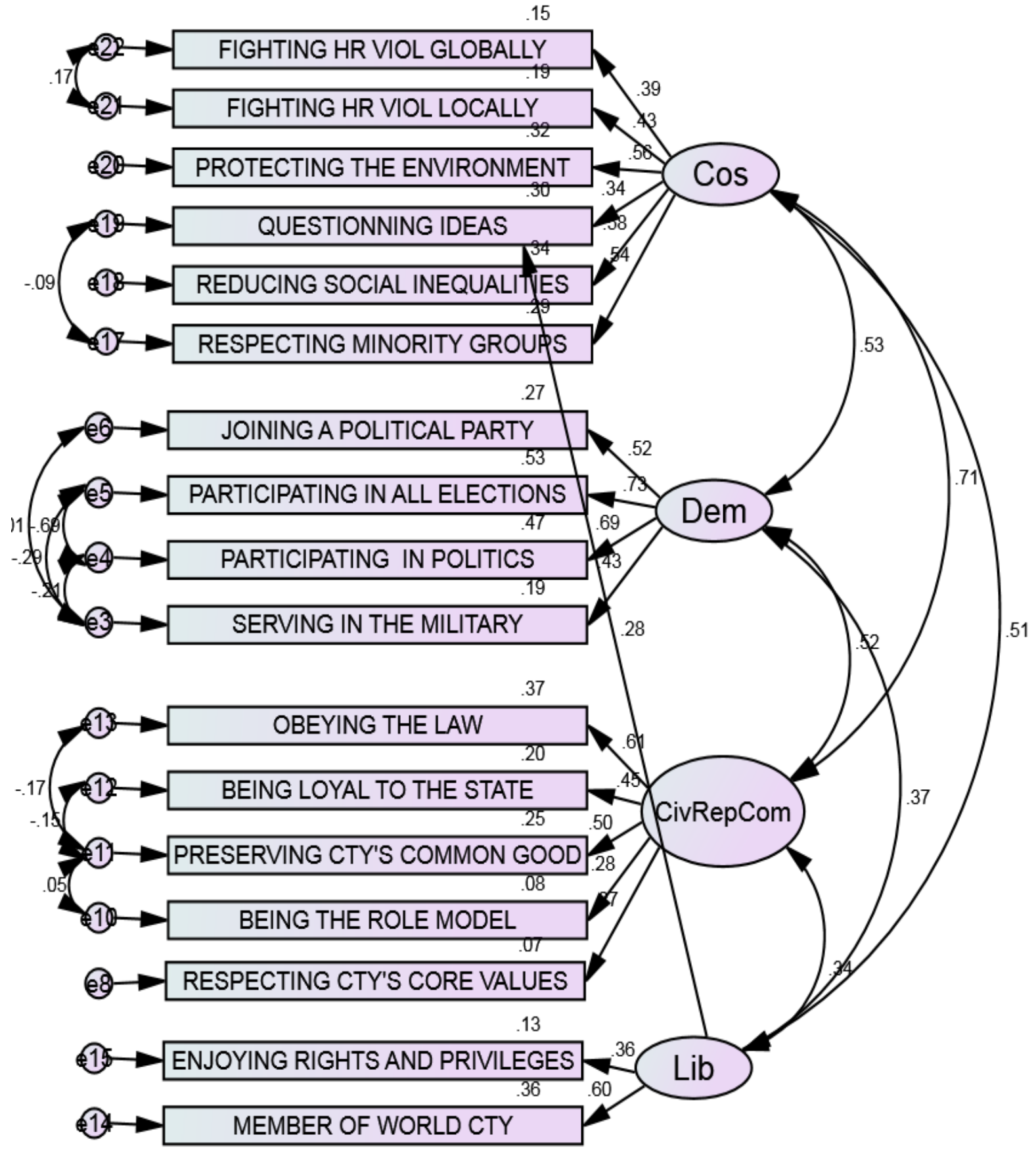

